\title{
Powder for Implantation Paste Dosage
}

\section{Form}

National Cancer Institute

\section{Source}

National Cancer Institute. Powder for Implantation Paste Dosage Form. NCI Thesaurus.

Code C149829.

Solid sterile preparation consisting of one or more powders intended to be mixed with the specified liquid or paste to obtain an implantation paste. 